\title{
Self-Representation and Fictionalysis
}

\author{
Daphne Marlatt
}

\begin{abstract}
Auto-représentation et fictionalyse
Toute biographie est une re-constitution fictive d'une vie réelle. Grâce à cette forme, les femmes peuvent rassembler ce qui est fragmenté et généralement considéré comme sans valeur (la maternité, leur sexe, le travail domestique etc.). Mais l'autobiographie va plus loin: elle est la coincidence entre fiction (le moi et les moi que nous pourrions être) et l'analyse (i.e. les rôles dévolus aux fermmes par le contexte socio-familial et culturel). Parce qu'elle est l'écriture comme vie, elle donne (à chaque fermme qui écrit) la possibilitéde tisser (texter) sa vie, de la rendre visible / lisible par toutes les autres femmes. L'autobiographie devient alors un contexte dans lequel d'autres femmes peuvent s'inscrire en tant que différence.
\end{abstract}

For the critic, the question behind autobiography seems to be first of all how does the writer represent herself? For the writer it is how do you represent others? An interesting differential which, in either case, brings up the notion of truth and how or whether it differs from fiction. The writer worries about the difference between how she sees the people she writes about and how they see themselves. The critic looks at the self that is being presented and its difference from what is known about the writer's life, the facts, say. Or 'the (f) stop of act' as Annie puts it in Ana Historic, isolating fact like the still photo as a moment frozen out of context, that context which goes on shifting, acting, changing after the f-stop has closed its recording eye. The fact a still frame. The self framed she suspects, caught in the ice of representation.

As if there were a self that existed beyond representation as some sort of isolatable entity. And then, for company's sake, your self-representation, your self and your self-representation sitting side by side or 
better yet, coinciding. And without that coincidence some one can say, 'Oh, she's making herself out to be...' Oh dear, fiction as falsity.

Fiction, however, has always included the notion of making, even making something up (as if that something had never existed before), and goes back to a very concrete Indo-European word, deigh, meaning to knead clay. In many creation myths, a goddess or a god molded us and made us, touched us into life, made us up. Out of nothing, out of a whole cloth as the saying goes. And so, this nothing-something, or this something that is nothing, we insist, as a species, on hanging desperately onto our Somethingness. Fact or photo or figure (even clay), separate from ground, but not ground, not that ... facelessness. Women are ground, women are nature - well, we know all this, how for us it's no small feat to be Something, given the ways our culture reinforces the notion that we are less Something than men. And yet we continually demonstrate our abilities to generate something out of almost nothing: a whole baby, a whole book, the whole cloth of a life.

To pick up that phrase 'out of whole cloth' is to find an odd reversal, given that 'whole' means healthy, undivided, intact, the whole of something. How is it that the whole phrase has come to mean pure fabrication, a tissue of lies? Whole the other side of hole, w (for women?) the transforming link. We can't seem to avoid the notion that making and the thing made - tissue, or text for that matter, since they come from the same root, have, at root, nothing: 'you made it up,' or more usually, 'you just made it up' (as if making were easy). In our culture of ready-mades, making anything is an accomplishment, making something of yourself even more so, but add that little word 'up' and you add speciousness, you add a sneer. Children learn that dressing themselves is an achievement but dressing up is only play, child's play as they say of something easy. Yet as children we know that play is not only easy, it is also absorbing and immensely serious, that play is the actual practice (not factual but act-ual) of who else we might be.

A powerful put-down that word 'up.' Does it imply we're trying to imitate the gods and have no business reaching a notch higher on the scale of creation, especially when it comes to creating ourselves? Or is that scale fictional too and 'up' merely indicates we' re getting close to something non-hierarchical and very real as in 'i'm waking up'? 
Perhaps what we wake up to in autobiography is a beginning realization of the whole cloth of ourselves in connection with so many others. Particularly as women analyzing our lives, putting the pieces together, the repressed, suppressed, putting our finger on the power dynamics at play. It is exactly in the confluence of fiction (the self or selves we might be) and analysis (of the roles we have found ourselves in, defined in a complex socio-familial weave), it is in the confluence of the two that autobiography occurs, the self writing its way to life, whole life. This is the practice of the imaginary in its largest sense, for without vision we can't see where we're going or even where we are. Autobiography is not separable from poetry for me on this ground i would call fictionalysis: a self-analysis that plays fictively with the primary images of one's life, a fiction that uncovers analytically that territory where fact and fiction coincide.

In Ana Historic, Annie and Ina discuss the difference between story and history, between making things up (out of nothing) and the facts, those frozen somethings of evidence. But what is evident to Annie is not always evident to Ina, because in each of them the seeing occurs in differently informed ways. Clearly, there are different kinds of seeing, as evidence by another little word, 'through': seeing through, which isn't prepared to take things at face value. For Annie the facts are 'skeletal bones of a suppressed body the story is,' and that suppressed body which can be resurrected by dint of making up is the unwritten story of who (else) each of the women in the book might be. It is through analysis, analysis of the social context each of them inhabit, that Annie can write her way through the bare bones of who they apparently are to the full sense and the full sensory body of who each of them might be, if they could imagine themselves to their fullest.

And why isn't the imaginary part of one's life story? Every poet knows it is, just as $i$ know that in inventing a life from Mrs. Richards, i as Annie (and Annie isn't me though she may be one of the selves i could be) invented a historical leak, a hole in the sieve of fact that let the shadow of a possibility leak through into full-blown life. History is not the dead and gone, it lives on in us in the way it shapes our thought and especially our thought about what is possible. Mrs. Richards is a historical leak for the possibility of lesbian life in Victorian British Columbia, which like some deep-packed bedrock continues to underlie the leather shops and tinted glass of our high-rise 
1990 's. We live in that context: the actuality of both. Just as we also live in the context of salmon rivers polluted with dioxins, harassed abortion clinics, Hong Kong's historic jitters, eco-islands of Sitka spruce, half-hidden memories of child abuse, and whatever hungry ghosts still pursue each one of us - to pull only a few threads of the whole cloth. The context is huge, a living tissue we live together with/in.

To write a whole autobiography, i mean autobiography in its largest sense of self writing life, not the life of the self but the life self writes its way to, the whole cloth, is to reach for what is almost unwriteable, a hole in that other sense. Yet autobiography until recently was set aside as a minor form, a sort of documentary support like letters or journal-writing, for the great texts. Its significance lay in its veracity, the faithfulness with which it followed the 'life-line', the overall narrative of its writer's life, without leaving any holes or gaps, certainly without contradiction. The 'life-line' after all represents a single line, just as the writer's representation of herself should be a true likenesslike what? Given the whole cloth, the truth of ourselves is so large it is almost impossible to write. It is full of holes, pulled threads, multiple lines, figures indistinct from ground.

Here we run up against the reductiveness of language which wants to separate - what do you mean threads? ground? Get your metaphors straight for god's sake, no for your reader's sake. Who's the creator here anyway? Maybe language after all, despite itself. But that's only if we can subvert its mainline story, that black stands to white as woman to man, that is, for the sake of definition (which language is all about) as ground to figure. Language defines Something, the subject let's say, as different from any thing and any other, who is always merely object. We begin to see the bias of the subject operating here and that this subject who so dominates the stage of representation is white, heterosexual, middle-class, monological, probably Christian and usually male. Wherever we as women overlap with any of those aspects, we inherit that bias. It leaks out everywhere in the most familiar of colloquial phrases, of idiomatic usage, in the very, indeed - and only by varying them (disrespectfully the subject might say, intent on the singular line of his story), only by altering them infinitesimally, undermining what they say, bending them into knots, into not's and un's, can we break the rigid difference between figure and ground 
which preserves that figure's hegemony, his 'truth.' No wonder women have such difficulty with the truth - such a single-minded / simple-minded truth it is, with no sense at all of the truth of the ground, of that which bears us in all our harrowing complexity: context.

Autobiography has come to be called 'life-writing' which i take to mean writing for your life and as such it suggests the way in which the many small real-other-i-zations can bring the unwritten, unrecognized, ahistoric ground of a life into being as a recognizable power or agency. This happens when we put together the disparate parts of our lives and begin to see the extensiveness of that cloth of connectedness we are woven into. Then we begin, paradoxically, to weave for ourselves the cloth of our life as we want it to be. For it is in the energetic imagining of all that we are that we can enact ourselves. Every woman we have read who has written about women's lives lives on in us, in what we know of our own capacity for life, and becomes part of the context for our own writing, our own imagining.

When text becomes context, when it leaves behind the single-minded project of following a singular life-line, when it drops out of narrative as climax and opts for narrative as interaction with what surrounds us, then we are in the presence of a writing for life, a writing that ditches dualistic polarities (the good guys vs. the bad guys, gays, bitches, blacks - you see how many of us there are), dodges the hierarchies (the achieved, the significant vs. the inessential, the failed, which goes to the root of our fear about life: was it all for nothing?) it's all there in the so-called 'nothing.' 